\title{
Values of Character Education: An Exploration Study on Assyura Day Celebration Tradition
}

\author{
Muhamad Yasir $^{1}$, Susilawati ${ }^{2}$ \\ \{susiwati512@gmail.com² \\ Universitas Indraprasta PGRI, Jakarta, Indonesia ${ }^{12}$
}

\begin{abstract}
Character education must continue to be instilled and developed both in educational institutions and in the community. This study discusses the character values in the tradition of celebrating the Assyura Day. The research was conducted in Kampung Choblong, Cibeureum Village, Cisarua District, Bogor Regency. The research was conducted using qualitative methods. The subjects of this study were residents of the Kampung Choblong. The data was collected by using triangulation technique. The results showed that the activities carried out on the day of Assyura included fasting, making suro porridge, distributing snacks to children for stall owners, sharing with orphans, and praying together. In the tradition of celebrating the Assyura Day, the local community has the perception that sharing with others will bring blessings in life. The values of character education that have been embedded in the celebration of Assyura Day include religion, tolerance, curiosity, love of peace, love of reading, social care, and responsibility.
\end{abstract}

Keywords: character education, tradition, celebration, Assyura Day

\section{Nilai-Nilai Pendidikan Karakter: Sebuah Studi Eksplorasi atas Tradisi Perayaan Hari Assyura}

\begin{abstract}
Abstrak. Pendidikan karakter harus terus ditanamkan dan dikembangkan baik di lembaga pendidikan maupun di lingkungan masyarakat. Penelitian ini membahas tentang nilai-nilai karakter dalam tradisi perayaan hari Assyura. Penelitian dilakukan di Kampung Choblong, Desa Cibeureum, Kecamatan Cisarua, Kabupaten Bogor. Penelitian dilakukan dengan metode kualitatif. Subjek penelitian ini adalah warga masyarakat kampung Choblong. Pengumpulan data dilakukan dengan teknik triangulasi. Hasil penelitian menunjukkan bahwa kegiatan yang dilakukan pada hari Assyura antara lain berpuasa, membuat bubur suro, membagikan jajanan kepada anak-anak bagi pemilik warung, berbagi dengan anak yatim, dan berdoa bersama. Dalam tradisi perayaan hari Assyura, masyarakat sekitar memiliki persepsi bahwa berbagi dengan sesama akan memberikan keberkahan dalam hidup. Adapun nilai-nilai pendidikan karakter yang telah tertanam dalam perayaan hari Assyura antara lain religius, toleransi, rasa ingin tahu, cinta damai, gemar membaca, peduli sosial, dan tanggung jawab.
\end{abstract}

Kata Kunci: pendidikan karakter, tradisi, perayaan, hari Assyura 


\section{Pendahuluan}

Manusia merupakan makhluk sosial yang selalu memerlukan orang lain dalam melangsungkan kehidupannya. Sebuah masyarakat yang tinggal di suatu wilayah tertentu akan memiliki keterikatan yang kuat dalam melaksanakan aturan-aturan dalam menjalankan proses kehidupan. Hal ini terjadi secara alami. Mereka melakukan kegiatan-kegiatan yang merupakan rutinitas mereka, kegiatan tersebut antara lain beribadah, bergotong royong, menghadapi tantangan dan rintangan serta ancaman dan lain sebagainya.

Sejatinya, sebuah kebiasaan yang dilakukan berulang-ulang dan dilakukan secara bersama-sama mejadi sebuah tradisi yang tidak bisa ditinggalkan begitu saja oleh masyarakat pemiliknya. Sebuah wilayah dengan tatanan kehidupan yang teratur tentu tidak terlepas dari peran akan seorang pengatur, pemimpin atau sosok yang dituakan dalam masyarakat tersebut. Dengan adanya seseorang atau beberapa orang yang dijadikan pemimpin yang mengatur perikehidupan anggota kelompok dan adanya ketaatan anggota kelompok terhadap pemimpinnya, maka timbul lah dalam kelompok itu suatu kekuasaan "pemerintahan" yang sangat sederhana. Pemimpin ini akan membawa masyarakat dan mendorongnya untuk selalu terlibat dalam setiap kegiatan dalam kehidupan bermasyarakat, tidak terkecuali dalam kegiatan-kegiatan yang sakral sebagai abdi Tuhannya. Acara- acara sakral tersebut merupakan kegiatan masyarakat dalam menanamkan nilai-nilai karakter sebagai sebuah acuan agar dapat hidup dengan berbagai kebaikan dalam bermasyarakat [1].

Berkarakter berarti memiliki sifat-sifat kepribadian bagi seseorang. Memiliki pribadi baik tentu tidak lepas dari pendidikan. Pendidikan yang dibicarakan di sini adalah pendidikan karakter. Pendidikan karakter sesungguhnya bersifat liberatif, yaitu sebuah usaha individu, baik secara pribadi (melalui pengolahan pengalamannya sendiri), maupun secara sosial (melalui pengolahan pengalaman atas struktur hidup bersama, khususnya perjuangan pembebasan dari struktur yang menindas) untuk menciptakan sebuah lingkungan yang dapat menghargai kebebasannya sebagai individu, sehingga individualitas dan keunikannya dapat semakin dihargai [2].

Pendidikan karakter merupakan kegiatan yang dilakukan secara sadar dan terencana dalam memfasilitasi dan membantu para peserta didik untuk mengetahui hal-hal yang baik dan luhur, mencintainya, memiliki kompetensi intelektual, berpenampilan menarik, dan memiliki kemauan yang keras untuk memperjuangkan kebaikan dan keluhuran serta dapat mengambil keputusan secara bijak. Sehingga, ia mampu memberikan kontribusi positif dalam kehidupan berbangsa dan bernegara [3].

Pendidikan karakter pada masyarakat Indonesia dapat ditanamkan dengan berbagai cara, salah satunya yaitu melalui tradisi yang dilakukan dalam merayakan hari-hari besar bersejarah. Melestarikan sebuah tradisi untuk memperoleh keberkahan dalam kehidupan banyak dilakukan di berbagai wilayah Indonesia. Istilah tradisi dapat dirumuskan sebagai sekumpulan praktik dan kepercayaan yang secara sosial ditransmisikan dari masa lalu, atau pewarisan kepercayaan/kebiasaan dari generasi yang satu kepada generasi selanjutnya [4]. Lalu tradisi berarti penyerahan, penerusan, dan komunikasi terus menerus. Tradisi bukan sesuatu yang "kolot" atau dari zaman dahulu, melainkan sesuatu yang masih terjadi sekarang ini juga [5]. Tradisi merupakan segala hal yang diwariskan dari masa lalu ke masa sekarang. Suatu hal yang diwariskan di masa kini dan masih memiliki ikatan kuat dengan masa lalu. Hal ini masih bisa disebut tradisi [6].

Kampung Choblong merupakan sebuah kampung yang terletak wilayah RT.03 RW.010 Desa Cibeureum Kecamatan Cisarua Kabupaten Bogor. Setiap tahun tanggal 10 bulan Syura, warga Kampung Choblong selalu melakukan tradisi perayaan hari Assyura. Meskipun 
kegiatan ini sudah jarang ditemui dalam tradisi masyarakat lainnya, Kampung Choblong tetap melakukannya. Pelaksanaan kegiatan perayaan hari Assyura ini menjadi salah satu strategi dalam penguatan pendidikan karakter di Kampung Choblong, terutama bagi generasi muda.

Dengan demikian, penelitian ini dilakukan dengan tujuan untuk mengetahui kegiatan apa saja yang dilakukan pada perayaan tradisi Assyura, mengetahui persepsi masyarakat dalam tradisi perayaan hari Assyura, dan untuk mengetahui penerapan pendidikan karakter apa saja yang tampak dalam perayaan hari Assyura.

Keutamaan penelitian ini berkaitan dengan penerapan pendidikan karakter sebagai bagian dari tatanan tujuan pendidikan nasional yang terdapat dalam pasal 3 undang-undang Sisdiknas no. 20 Tahun 2003 untuk mengembangkan potensi manusia yang beriman dan bertakwa kepada Tuhan Yang Maha Esa berakhlak mulia, sehat, berilmu, cakap, kreatif, mandiri, dan menjadi warga negara yang demokratis serta bertanggung jawab

Dalam melakukan penelitian ini, peneliti menyertakan penelitian terdahulu yang relevan dengan judul yang diangkat. Pertama, penelitian yang dilakukan oleh Amin dengan judul Model Pendidikan Karakte Berbasis Tradisi KATOBA Dalam Budaya Masyarakat Muna di Sulawesi Tenggara. Penelitian ini bicara tentang tradisi Katoba yang dikenal sebagai model Pendidikan karakter berbasis kearifan lokal. Model pendidikan karakter berbasis Katoba ini bertujuan untuk memperkenalkan nilai-nilai agama sejak dini, yakni pada usia 7-12 tahun, menanamkan ajaran akhlak dasar pada anak dengan memperkenalkan hal-hal yang mengandung kebaikan dan keburukan dalam bahasa Muna nimotehi be nimokodo (hal-hal yang dilarang dan boleh dilakukan) mengajarkan kepada anak-anak nilai-nilai untuk menghargai kehidupan sosial, dan menghindarkan diri pada hal-hal yang bukan miliknya (hakunasi).

Kedua, penelitian yang dilakukan oleh Hermawan dengan judul Implementasi Pendidikan Karakter Pada Kegiatan Student Exchange SD Muhammadiyah Paesan Pekalongan. Hasil penelitian ini menunjukkan bahwa partisipasi masyarakat desa Kranggan Tresono Batang dalam kegiatan Student Exchange dapat dikatakan aktif dan baik. Prinsip-prinsip yang muncul dan tampak di antaranya: localization, integrated delivery of service, accept diversity, dan institutional responsive. Nilai-nilai karakter yang muncul dalam kegiatan Student Exchange yakni sholeh dan kreatif, bersahabat dan peduli sosial maupun lingkungan. Namun dalam sikap kemandirian masih belum tampak dengan baik. Faktor pendukung dalam kegiatan ini adalah hubungan kekeluargaan dan kesamaan dalam organisasi, sehingga mudah untuk koordinasi. Sedangkan faktor-faktor penghambat adalah mayoritas orang tua menjenguk anakanaknya di desa, dan masyarakat Kranggan juga kadang merasa malu jika tidak melayani dengan baik. Maka dari itu diperlukan komitmen antara guru, wali murid, dan masyarakat Kranggan terhadap aturan-aturan yang sudah disepakati.

Sedangkan penelitian ini akan membahas mengenai implementasi pendidikan karakter dalam tradisi perayaan hari Assyura. Pendidikan ini diharapkan dapat menjadi sebuah tolak ukur tentang sejauh mana pendidikan karakter dibentuk dalam lingkungan masyarakat Kampung Choblong RT.03 RW.010 Desa Cibeureum Kecamatan Cisarua Kabupaten Bogor.

\section{Metode}

Penelitian ini adalah penelitian kualitatif. Penelitian kualitatif merupakan penelitian yang berusaha melihat kebenaran-kebenaran atau membenarkan kebenaran. Namun, di dalam melihat kebenaran tersebut, tidak cukup hanya dengan melihatnya dari sesuatu yang nyata, 
akan tetapi kadangkala perlu pula melihat sesuatu yang bersifat tersembunyi yang perlu dilacak lebih jauh lagi ke balik sesuatu yang nyata tersebut [7].

Pendekatan dalam penelitian ini menggunakan etnografi. Etnografi merupakan sebuah deskripsi - kisah atau laporan tertulis - mengenai suatu kelompok masyarakat yang dihasilkan oleh para peneliti dalam periode waktu cukup panjang, guna membenamkan diri dalam konteks kelompok atau komunitas yang diteliti. Tujuannya adalah menggambarkan realitas sosial sebuah kelompok, sehingga dapat dipahami oleh pembaca Etnografi [8].

Penelitian ini dilaksanakan di Kampung Choblong Desa Cibeueum Kecamatan Cisarua Kabupaten Bogor. Pelaksanaan penelitian dimulai pada bulan September-Desember 2019. Adapun subjek penelitian ini adalah seluruh warga masyarakat Kampung Choblong Desa Cibeuereum Kecamatan Cisarua Kabupaten Bogor.

Pengambilan sampel menggunakan purposive sampling. Adapun pengumpulan data dilakukan dengan triangulasi. Pengumpulan data merupakan salah satu kegiatan paling krusial, sekaligus paling sulit dilakukan di dalam penelitian karena memerlukan metode dan pelaksanaan yang tepat [9]. Analisis data dilakukan dengan menggunakan analisis domain. Analisis domain adalah memperoleh gambaran umum dan menyeluruh dari objek penelitian atau situasi sosial. Untuk uji keabsahan, peneliti menggunakan uji kredibilitas, transferabilittas, depenabilitas, dan konfirmabilitas [10].

\section{Hasil dan Pembahasan}

Tradisi perayaan hari Assyura di Kampung Choblong tidak diketahui siapa yang memulainya. Namun, secara turun temurun, para tokoh agama di Kampung Choblong mengajak masyarakat untuk mengagungkan hari yang dianggap mulia ini. Beberapa warga masyarakat melaksanakan tradisi perayaan hari Assyura berdasarkan informasi tertulis dari beberapa kitab umat muslim yang dikaji oleh tokoh agama dan kemudian diinformasikan kembali kepada masyarakat. Tradisi perayaan hari Assyuro sendiri banyak dilakukan oleh umat muslim di berbagai daerah dengan ritual yang beragam. Ritual-ritual tersebut tidak lain untuk mengharap keberkahan dalam hidup masyarakat tersebut. Adapun terkait dengan tradisi perayaan hari Assyura ini antara lain merupakan realitas sejarah besar bagi kalangan umat muslim: tradisi perayaan hari Assyura pada hari ke-10 bulan Muharram berkenaan dengan hari-hari bersejarah dalam agama Islam. Pada hari Asura Allah menciptakan 'Arsy, langit, bumi, matahari, bulan, bintang, dan surga; nabi Adam diciptakan, bertaubat dan dimasukkan ke dalam surga; nabi Idris diangkat ke tempat yang tinggi; nabi Nuh merapat ke bukit Judi; nabi Ibrahim dilahirkan dan diselamatkan dari api unggun Raja Namrud; nabi Sulaiman diberikan karunia kerajaan yang besar; nabi Yunus dikeluarkan dari perut ikan; dan nabi Isya dilahirkan serta diangkat ke langit [11].

Tradisi perayaan hari Assyura di Kampung Choblong dilakukan setiap tahun dan masyarakat sangat antusias bersuka cita menyambutnya. Terdapat beberapa kegiatan yang biasa dilakukan pada hari Assyura oleh masyarakat kampung Choblong. Selain itu, terdapat pula persepsi masyarakat terhadap tradisi perayaan hari Assyura yang dianggap memiliki sejarah yang sangat berarti bagi umat muslim. Selain itu, tradisi perayaan hari Assyura mengandung beberapa pendidikan karakter yang harus terus dikembangkan, terutama pada generasi muda supaya menjadi manusia yang berkarakter positif. Berikut adalah temuan yang diperoleh peneliti dalam penelitian ini: 


\subsection{Kegiatan pada hari Assyura \\ 3.1.1 Puasa}

Pada hari Assyura, masyarakat berpuasa sebagai tanda bersyukur. Hassan (2016:135) menyatakan bahwa Assyura adalah hari ke-10 pada bulan Muharram. Dalam sejarah Arab, hari Asyura (10 Muharram) adalah hari bersejarah. Pada hari itu orang-orang jahiliyah berpuasa. Setiap suku mengadakan perayaan dengan mengenakan pakaian baru dan menghias kota-kota mereka. Pada hari Assyura pula Allah menyelamatkan nabi Musa as., dan kaumnya dari kezaliman Fir'aun. Oleh karena itu, nabi Musa as., berpuasa sebagai rasa syukur kepada Allah.

\subsubsection{Membuat bubur suro dan membagikannya kepada tetangga yang datang}

Sudah menjadi kebiasaan warga masyarakat kampung Choblong membuat bubur pada hari perayaan hari Assyura. Biasanya, masyarakat membuat bubur putih yang disebut sebagai bubur suro. Bubur tersebut biasanya dibagikan kepada warga lain di kampung tersebut. Sama halnya tempat-tempat yang merayakan hari Assyura, seperti di Jawa, perayaan Suro atau Asuro dimeriahkan dengan menghadirkan tumpeng yang diarak di tengah kampung. Di Sumatera Barat dan Bengkulu disebut Tabuik (Tabut) dan di Sulawesi Selatan lazim dengan perayaan mappecasure. Perayaan Asyura di Sulsel selalu dilengkapi dengan bubur tujuh rupa. Membuat dan membagikan bubur ini merupakan rasa syukur atas keberkahan yang diberikan kepada masyarakat kampung Choblong.

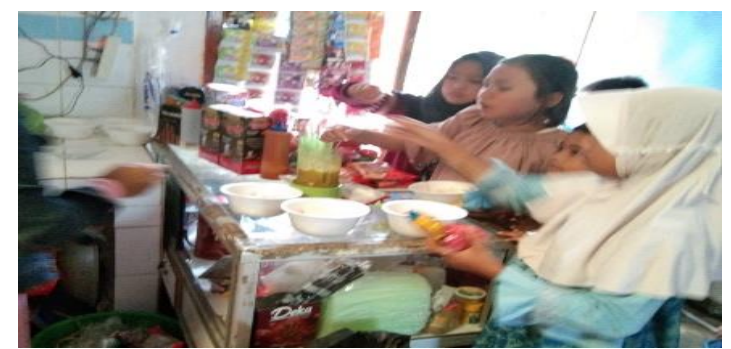

Gambar 1. Membuat dan membagikannya kepada masyarakat itu sendiri terutama anak-anak

\subsubsection{Membagikan jajanan kepada anak-anak bagi pemilik warung}

Pada hari Assyura para pemilik warung yang ada di kampung Choblong membagikan jajanan kepada anak-anak. Anak-anak biasanya ramai-ramai mendatangi warung-warung dan bergembira karena mendapatkan jajanan gratis pada hari itu. Pemilik warung tidak memperhitungkan untung rugi pada hari tersebut. Bagi mereka keberkahan akan datang lebih melimpah lagi jika mereka mau berbagi dengan sesama, salah satunya menyenangkan hati anak-anak, terutama anak yatim. Hal ini terlihat unik karena mungkin tradisi seperti ini belum terlihat di wilayah lain.

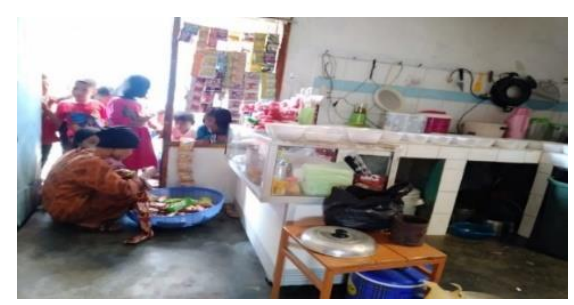

Gambar 2. Pemilik warung memberikan jajanan secara gratis 


\subsubsection{Bordoa bersama agar dihindarkan dari malapetaka}

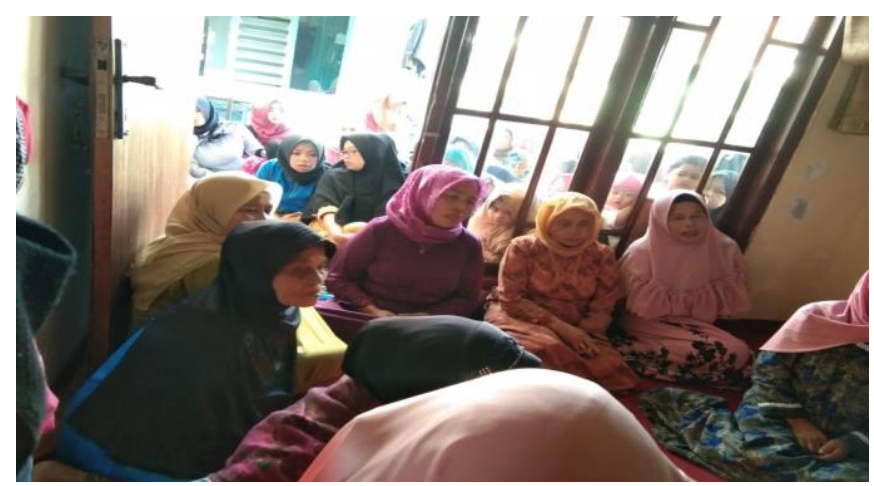

Gambar 3. Berdoa bersama

Masyarakat kampung Choblong begitu intim dengan kegiatan keagamaannya. Setiap hari ada saja waktu untuk mencari ilmu di majlis-majlis ta'lim baik yang ada di Kampung Choblong sendiri maupun di luar kampung. Berdoa bersama sudah menjadi rutinitas masyarakat Kampung Choblong, termasuk ketika merayakan tradisi Assyura. Mereka berdoa bersama meminta agar dijauhkan dari segala malapetaka dan didekatkan pada keberkahan hidup.

\subsection{Perspektif masyarakat terhadap tradisi perayaan hari Assyura}

Masyarakat Kampung Choblong memiliki pandangan yang bijaksana terhadap tradisi perayaan hari Assyura. Segala aktivitas dan ritual dilakukan semata-mata karena ingin melakukan kebaikan. Bukan hanya kebaikan yang dicari, namun juga menjauhkan diri dari perbuatan dosa yang akan membawa mereka pada kesengsaraan hidup di masa yang akan datang. Mereka merasa bahagia dapat berkumpul dan berbagi dengan sesama karena mereka meyakini bahwa kebiasaan berbagi dengan sesama akan terus tertanam dalam diri mereka bahkan akan mengajarkan kebiasaan tersebut pada anak cucu mereka agar suka dan bahagia jika bisa menjadi bagian dari masyarakat yang dapat memberikan manfaat pada masyarakat lainnya.

\subsubsection{Nilai-nilai pendidikan karakter yang tertanam dalam tradisi perayaan hari} Assyura.

Kegiatan penyambutan hari Assyuro mengandung beberapa nilai-nilai pendidikan karakter yang harus selalu ditanamkan terus menerus pada generasi ke generasi antara lain:

3.2.1.1 Religius. Kegiatan penyambutan hari Assyura mengandung nilai religius. Kepatuhan warga masyarakat terhadap ajaran agamanya terus dibina dan dikembangkan. Para tokoh masyarakat dan agama selalu menjadi panutan warganya supaya terus dapat membimbing masyarakat supaya tetap pada kepatuhannya untuk senantiasa beribadah.

3.2.1.2 Toleransi. Jika warga kampong Choblong sangat bahagia menyambut hari Assyura dengan melakukan banyak kebaikan. Setiap tahun kegiatan ini dilaksanakan oleh warga masyarakat secara turun temurun. Adapun sikap toleransi warga masyarakat terhadap warga masyarakat lainnya yang berbeda tempat yang tidak melakukan penyambutan, seperti kebiasaan mereka dalam menyambut hari Assyura tetap dijaga. 
3.2.1.3 Rasa Ingin Tahu. Bagi warga pendatang mungkin belum terbiasa melakukan kebiasaan-kebiasaan pada hari Assyura, namun mereka belajar untuk memahami dan memaknai hari Assyura. Mereka belajar tentang segala pengetahuan-yang melatar belakangi adanya kegiatan penyambutan hari Assyura, belajar mengambil manfaat dan kebaikan dari kegiatan ini kepada para tokoh masyarakat dan para ulama.

3.2.1.4 Cinta Damai. Kegiatan penyambutan hari Assyura ini mencerminkan bahwa warga masyarakat RT.02 dan RT.03 cinta damai. Mereka saling menyapa, mendoakan, dan selalu mempererat tali persaudaraan.

3.2.1.5 Gemar membaca. Melalui kegiatan penyambutan hari Assyura, warga masyarakat menjadi ingin menambah wawasan mengenai sejarah yang sangat penting untuk dipelajari agar menjadi bekal pengetahuan yang akan kembali diajarkan kepada generasi selanjutnya dengan membaca kisah-kisah, kitab-kitab yang menjelaskan makna hari Assyura atau menyimak tokoh agama yang menceritakan berbagai kisah dan sejarah hari Assyura.

3.2.1.6 Peduli sosial. Pendidikan karakter yang terkandung dalam kegiatan penyambutan hari Assyura ini antara lain mendidik masyarakat untuk senantiasa dapat peduli kepada orang lain yang membutuhkan bantuan. Keunikan yang terjadi pada saat penyambutan hari Assura ini antara lain warga saling membagikan makanan, yang memiliki warung pada hari tersebut membagi-bagikan makanannya terutama untuk anak-anak kecil. Semua warung yang ada di RT.02 dan RT.03 memberikan makanan untuk anak-anak yang sengaja berkeliling untuk memperoleh makanan. Selain itu, warga masyarakat biasa membuat bubur beras kemudian dibagikan kepada warga lainnya. Kegiatan-kegiatan ini pun sudah sejak lama secara turun menurun dilakukan sebagai bentuk peduli kepada sesama.

3.2.1.7 Tanggung Jawab. Sebagai masyarakat yang bertanggung jawab akan selalu menjalankan tugas dan kewajibannya baik itu sebagai pemimpin untuk diri sendiri maupun orang lain. Masyarakat Kampung Choblong merasa bahwa berbuat kebaikan, menjalankan ibadah dengan berbagai kegiatan, termasuk kegiatan membagikan makanan kepada orang lain sebagai tanggung jawab sebagai seorang muslim.

Hari Assyura adalah hari ke-10 pada bulan Muharram dalam kalender Hijriyah. Sedangkan Assyura sendiri berarti kesepuluh. Selain sebagai pelaksanaan nilai-nilai karakter bangsa, kegiatan penyambutan hari Assyuro merupakan kegiatan rutin setiap tahun yang dilakukan secara turun temurun dari beberapa generasi sebelumnya. Kegiatan penyambutan hari Assyura juga dimanfaatkan sebagai sumber pembelajaran mengenai beberapa peristiwa bersejarah dalam agama Islam. Selain itu, penyambutan hari Assyura dijadikan sebagai media untuk menanamkan pendidikan karakter sejak dini kepada warga masyarakat karena di dalamnya terkandung nilai-nilai karakter yang harus terus dipupuk dan dikembangkan agar menjadi manusia yang berbudi luhur dan bermartabat.

Menanggapi penanaman nilai-nilai karakter pada kegiatan penyambutan hari Assyura, salah satu tokoh agama bapak Muhammad Afiffudin menjelaskan satu persatu implementasi pendidikan karakter dalam kegiatan penyambutan hari Assyura seperti yang tersebut di atas.

Kegiatan perayaan hari Assyura merupakan penanaman pendidikan karakter pada generasi penerus bangsa, sehingga kegiatan ini dirasa perlu untuk selalu dilestarikan dari generasi ke generasi, khususnya di kampung Choblong. Pembentukan karakter dilakukan melalui berbagai kegiatan dalam tradisi perayaan hari Assyura yang melibatkan seluruh warga dalam menanamkan serta mengembangkan secara konsisten pembentukan karakter positif. Penguatan pembentukan karakter tidak hanya merupakan tugas bagi para pendidik di sekolah 
saja, namun merupakan tanggung jawab dan melibatkan seluruh aspek yang memiliki tanggung jawab terhadap pembentukan karakter, seperti keluarga dan juga masyarakat pada umumnya. Hal ini sesuai dengan yang disampaikan oleh Suprayitno \& Wahid bahwa solusi yang paling tepat dalam membangun karakter bangsa di era milenial saat ini adalah membangun dan menata kembali karakter dan watak bangsa Indonesia sendiri dengan terus melakukan pengembangan diri untuk menerapkan pendidikannya di masyarakat [12].

\section{Simpulan}

Dari hasil dan pembahasan di atas, peneliti memperoleh simpulan bahwa kegiatan yang dilakukan dalam tradisi perayaan hari Assyura antara lain membiasakan berpuasa, membuat, dan membagikan bubur suro, membagikan jajanan kepada anak-anak bagi yang memiliki warung, serta berdoa bersama untuk mendapat keberkahan dalam kehidupan. Persepsi masyarakat terhadap tradisi perayaan hari Assyura dilakukan semata-mata karena ingin melakukan kebaikan. Bukan hanya kebaikan yang dicari, namun juga menjauhkan diri dari perbuatan dosa yang akan membawa mereka pada kesengsaraan hidup di masa yang akan datang. Nilai pendidikan karakter yang muncul dalam tradisi perayaan hari Assyura antara lain: religius, toleransi, rasa ingin tahu, cinta damai, gemar membaca, peduli sosial, dan tanggung jawab.

\section{Referensi}

[1] Suhadi I, AM. Sinaga. Wawasan Kesatuan dalam Rangka Negara Kesatuan Republik Indonesia. Lembaga Administrasi Negara RI. 2003

[2] Koesoema. Pendidikan Karakter. Jakarta: PT. Grasindo. 2007, 194.

[3] Ali, AM. Pendidikan Karakter. Konsep dan Implementasinya. Jakarta: KENCANA. 2018,13.

[4] Tyaya H, Sudarminta. Manusia Sebagai Penafsir. Yogyakarta: Kanisius. 2005

[5] Yosef L. Makna Hidup Dalam Terang Iman Katolik. Agama-agama Membantu Manusia Menggumuli Makna Hidupnya. Yogyakarta: Kanisius. 2005

[6] Suryana H. Pengertian Budaya dan Tradisi. https://hisham.id/pengertian-budaya-dan-tradisi.html. Diakses pada tanggal 26 Februari 2019.

[7] Mamik. Metodologi Kualitatif. Sidoarjo: Zifatama Publisher. 2015,15.

[8] Daymon C, Immy. Riset Kualitatif dalam Public Relations \& Marketing Communications. Yogyakarta: Bentang. 2002, 204.

[9] Marwadani. Praktis Penelitian Kualitatif Teori Dasar Dan Analisis Data Dalam

[10] Yusuf, AM. Metode Penelitian Kuantitatif, Dan Penelitian Gabungan. Jakarta: KENCANA. 2017, 410.

[11] Ghazali, S. Misteri Bulan Suro. Jakarta: PT. Suka Buku Kita. 2010

[12] Suprayitno A, Wahid. Pendidikan Karakter di Era Milenial. Yogyakarta: DEEPUBLISH. 2020, 156. 